Report of Investigation 2019-4

\title{
REGIONAL TSUNAMI HAZARD ASSESSMENT FOR SHEMYA, ALASKA
}

E.N. Suleimani, J.B. Salisbury, D.J. Nicolsky, and R.D. Koehler

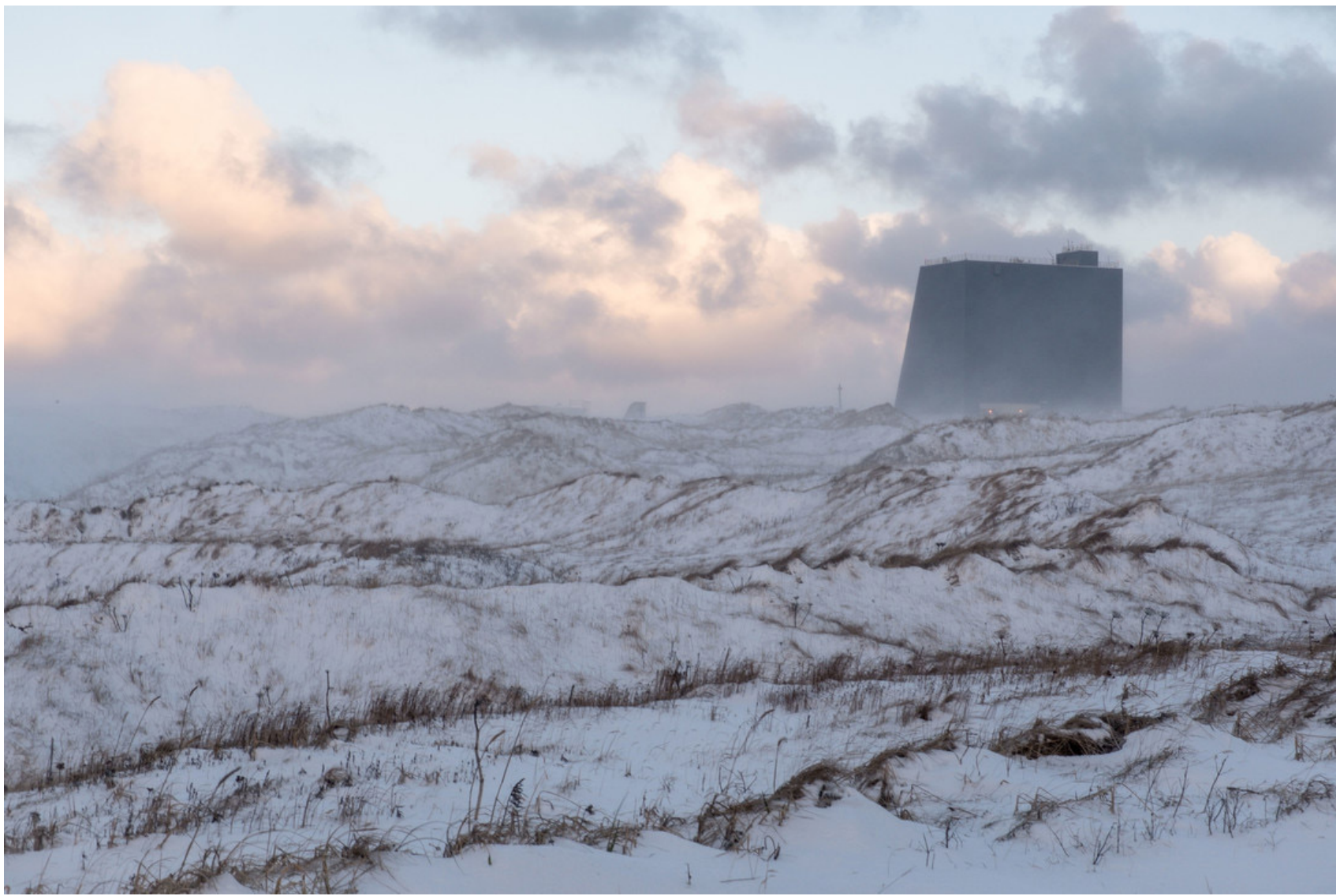

AN/FPS-108 Cobra Dane radar, located at Eareckson Air Station, on Shemya Island, Alaska, collects radar metric and signature data on foreign ballistic missile events and space surveillance data on new foreign launches and satellites in low-Earth orbit (U.S. Air Force/Brandon Rail). www.ndu.edu/News/Images/igphoto/2001938666/ 



\section{REGIONAL TSUNAMI HAZARD ASSESSMENT FOR SHEMYA, ALASKA}

E.N. Suleimani, J.B. Salisbury, D.J. Nicolsky, and R.D. Koehler

Report of Investigation 2019-4

State of Alaska

Department of Natural Resources

Division of Geological \& Geophysical Surveys 
STATE OF ALASKA

Michael J. Dunleavy, Governor

\title{
DEPARTMENT OF NATURAL RESOURCES
}

Corri A. Feige, Commissioner

\section{DIVISION OF GEOLOGICAL \& GEOPHYSICAL SURVEYS}

\author{
Steve Masterman, State Geologist and Director
}

Publications produced by the Division of Geological \& Geophysical Surveys (DGGS) are available for free download from the DGGS website (dggs.alaska.gov). Publications on hard-copy or digital media can be examined or purchased in the Fairbanks office:

Alaska Division of Geological \& Geophysical Surveys 3354 College Rd., Fairbanks, Alaska 99709-3707

Phone: (907) 451-5010 Fax (907) 451-5050

dggspubs@alaska.gov|dggs.alaska.gov

DGGS publications are also available at:

Alaska State Library,

Historical Collections \& Talking Book Center

395 Whittier Street

Juneau, Alaska 99811

Alaska Resource Library and Information Services (ARLIS)

3150 C Street, Suite 100

Anchorage, Alaska 99503

Suggested citation:

Suleimani, E.N., Salisbury, J.B., Nicolsky, D.J., and Koehler, R.D., 2019, Regional tsunami hazard assessment for Shemya, Alaska: Alaska Division of Geological \& Geophysical Surveys Report of Investigation 2019-4, 13 p., 1 sheet.

doi.org/10.14509/30193
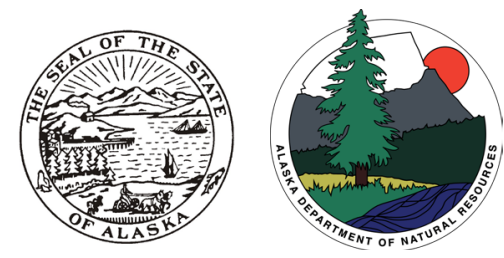


\section{Contents}

Abstract t.1.

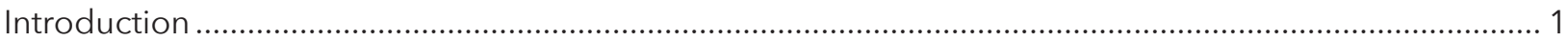

Project Background: Regional and Historical Context........................................................................ 3

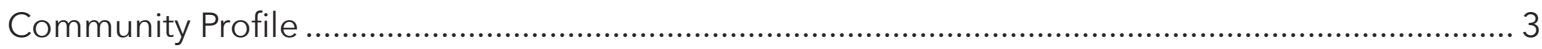

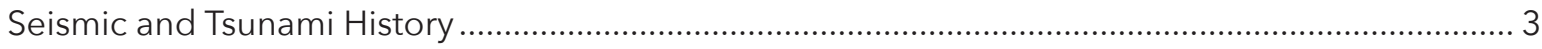

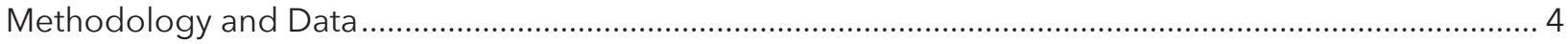

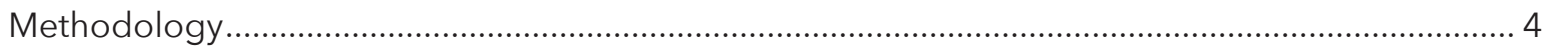

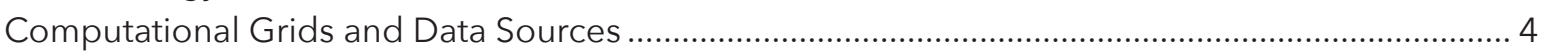

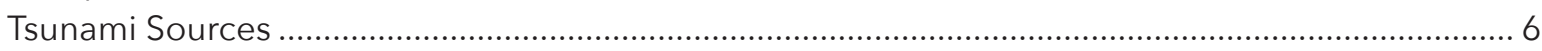

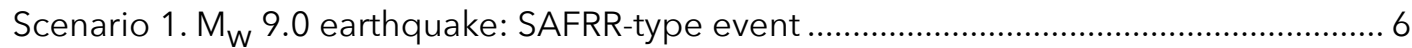

Scenario 2. $M_{W} 9.0$ earthquake: Maximum slip at 15-25 km (9-15 mi) depth ..................... 6

Scenario 3. $M_{W} 9.0$ earthquake: Maximum slip at 25-35 km (15-22 mi) depth................... 8

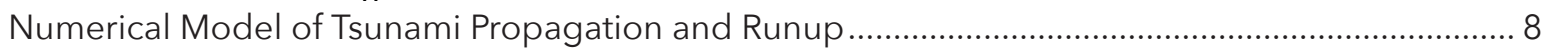

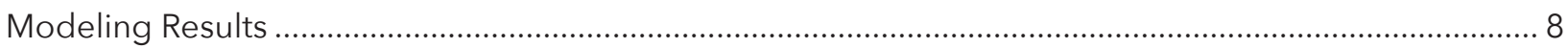

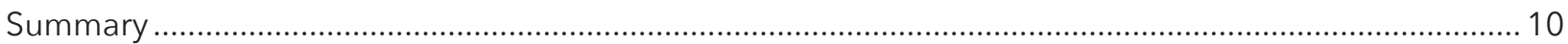

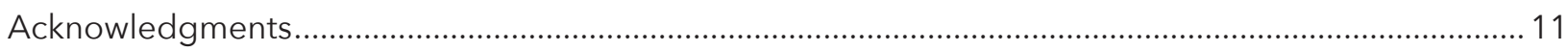

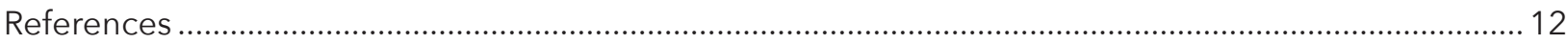

\section{Figures}

Figure 1. Map of the western Aleutian Islands

Figure 2. Nested bathymetry/topography grids for numerical modeling of tsunami

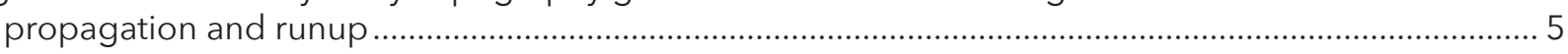

Figure 3. Vertical coseismic deformations corresponding to scenarios 1-3 .......................................... 7

Figure 4. Maximum tsunami heights for scenarios 1-3 in the level 3 grid for Shemya Island .................. 9

Figure 5. Maximum composite tsunami height extrapolated on Shemya Island .................................... 10

Figure 6. Time series of water level for scenarios $1-3$ offshore Shemya Island ....................................... 11

\section{Tables}

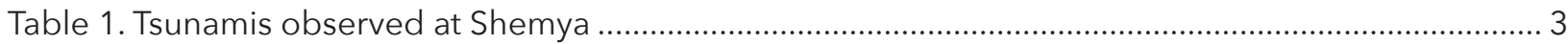

Table 2. Nested grids used to compute propagation of tsunami waves generated in the Pacific

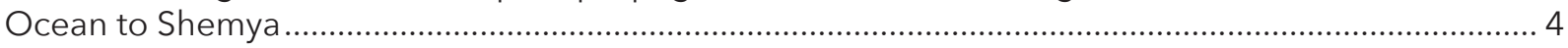

Table 3. Significant credible tsunami sources for Shemya ........................................................................ 8

\section{Map Sheets}

Sheet 1. Tsunami hazard map for Shemya, Alaska 



\title{
REGIONAL TSUNAMI HAZARD ASSESSMENT FOR SHEMYA, ALASKA
}

\author{
E.N. Suleimani ${ }^{1}$, J.B. Salisbury ${ }^{2}$, D.J. Nicolsky ${ }^{1}$, and R.D. Koehler ${ }^{3}$
}

\begin{abstract}
We assess potential tsunami hazard for Eareckson Air Station on Shemya Island, Alaska. The primary tsunami hazard for this installation is considered to be near-field, with the major threat originating from tsunamigenic earthquakes along the Alaska-Aleutian megathrust. We numerically model tsunamis generated by three different megathrust earthquakes, analyze tsunami wave dynamics, and develop approximate tsunami hazard maps for Eareckson Air Station (formerly "Shemya Station"). The hypothetical tsunami scenarios that we examined simulate $M_{W} 9.0$ megathrust earthquakes with a slip distribution in the $5-54 \mathrm{~km}$ (3-33 $\mathrm{mi}$ ) depth range along the Alaska-Aleutian megathrust. The maximum runup heights are $40 \mathrm{~m}$ (131 ft) on the northern side of Shemya Island, and $58 \mathrm{~m} \mathrm{(190} \mathrm{ft)} \mathrm{on} \mathrm{the} \mathrm{southern} \mathrm{side}$ of the island. Results presented here are intended to provide guidance to local emergency management agencies in initial tsunami inundation assessment, evacuation planning, and public education for mitigation of future tsunami hazards.
\end{abstract}

\section{INTRODUCTION}

Tsunami hazards along Alaska’s Pacific coastline are high. Virtually all of Alaska's southern and southeastern coasts are defined by major offshore fault systems. Unlike tsunamis that are caused by distant earthquakes on the other side of the Pacific, Alaska's greatest tsunami hazards originate just offshore and can inundate coastlines within an hour of a causative earthquake. This reduces the time available to respond and evacuate, and can produce drastically higher wave heights than far-traveled tsunamis. Because many Alaska communities hug the shoreline (due to some combination of steep mountains, dense forests, and/or reliance on the open water for transportation), many Alaska communities are within the tsunami inundation zone and are at risk of rapid flooding. In addition to earthquake-generated (i.e., tectonic) tsunamis, mass movements of sediments down slopes (either on land or in the ocean) can also generate tsunamis. While rapid tsunami flooding is the immediate concern after a large coastal earthquake, dangerous near-shore ocean currents and permanent changes to the local coastline are additional concerns.

The local, tectonic tsunami danger to communities in the Aleutian Islands comes primarily from the Alaska-Aleutian subduction zone (fig. 1). This subduction zone marks the boundary between the Pacific plate to the south and the North American plate to the north. Relative to the North American plate, the Pacific Plate is moving northwest at approximately $5-8 \mathrm{~cm}$ (2-3 inches) per year, colliding with the North American plate and diving beneath it in a process known as subduction. The latest sequence of large megathrust earthquakes began in 1938 with a $\mathrm{M}_{\mathrm{W}} 8.3$ earthquake west of Kodiak Island (Estabrook and others, 1994). Four subsequent events, the $1946 \mathrm{M}_{\mathrm{W}} 8.6$ Aleutian (Lopez and Okal, 2006), $1957 \mathrm{M}_{\mathrm{W}} 8.6$ Andreanof Islands (Johnson and others, 1994), 1964 $\mathrm{M}_{\mathrm{W}} 9.2$ Great Alaska (Kanamori, 1970), and 1965 $\mathrm{M}_{\mathrm{W}}$ 8.7 Rat Island (Wu and Kanamori, 1973)

\footnotetext{
${ }^{1}$ Alaska Earthquake Center, Geophysical Institute, University of Alaska, P.O. Box 757320, Fairbanks, Alaska 99775-7320; ensuleimani@alaska.edu

${ }^{2}$ Alaska Division of Geological \& Geophysical Surveys, 3354 College Rd., Fairbanks, Alaska 99709-3707.

${ }^{3}$ Nevada Bureau of Mines and Geology, Mackay School of Earth Science and Engineering, University of Nevada, Reno, 1664 North Virginia Street, MS 178, Reno, NV 89557
} 


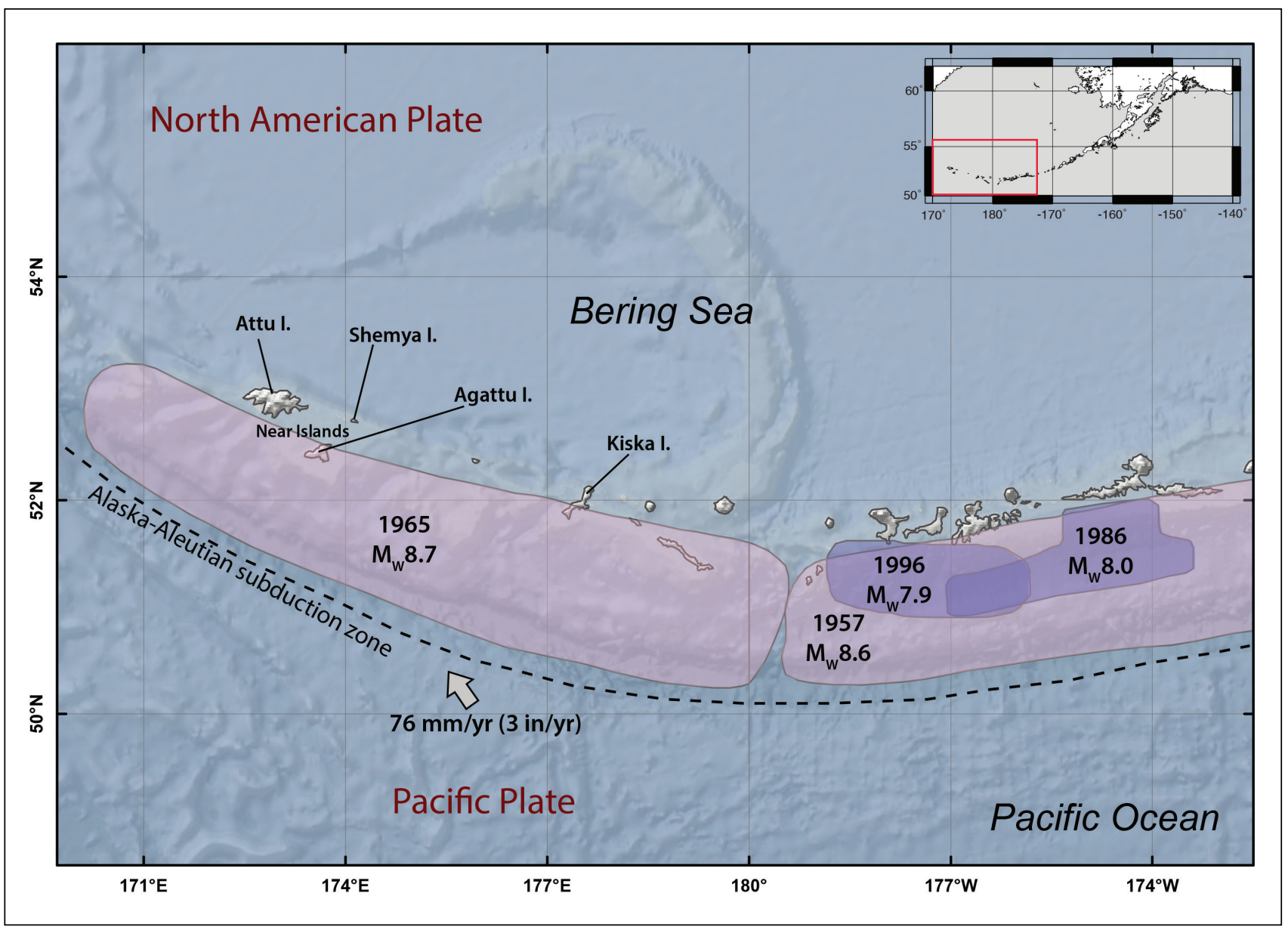

Figure 1. Map of the western Aleutian Islands, showing the Shemya Island region. The rupture areas in the latest sequence of great and large earthquakes are shown by shaded polygons.

earthquakes, ruptured almost the entire length of the megathrust. Tsunamis generated by these great earthquakes reached Alaska coastal communities within minutes and resulted in widespread damage and loss of life (National Centers for Environmental Information [NCEI; formerly known as National Geophysical Data Center] Global Historical Tsunami Database, doi.org/10.7289/V5PN93H7).

The specifics of tsunami hazards are particular to each community and vary considerably over large regions. The shape of the coastline, local bathymetry, and topography all affect tsunami impacts. More importantly, however, is the earthquake source (the location, size, and style) being considered and the community's location relative to that earthquake.

The impacts of future earthquakes and tsunamis can be reduced if citizens, emergency managers, and city planners take steps to mitigate the hazards. This report is intended to support hazard mitigation efforts by providing an approximate tsunami hazard estimate for Shemya. The scenario earthquakes, numerical tsunami models, and resulting map are developed on a regional level and lack the precision of studies that are fully tailored to individual communities (e.g., Nicolsky and others, 2013; Nicolsky and others, 2014; Suleimani and others, 2013, 2015). The current study does not include sensitivity tests and is based on three scenario earthquakes. Even so, the results provide a good first approximation of tsunami hazard. The maps, documentation, and available digital data provide a foundation for public education, support the development of evacuation procedures, and provide insights intended to improve community resilience. 


\section{PROJECT BACKGROUND: REGIONAL AND HISTORICAL CONTEXT \\ Community Profile}

Eareckson Air Station (a.k.a. Shemya or Shemya Station), on Shemya Island (52 $42^{\prime} 44^{\prime \prime} \mathrm{N}$, $174^{\circ} 06^{\prime} 49^{\prime \prime} \mathrm{E}$ ), is at the western end of the Aleutian Islands chain, east of the larger Attu Island in the Near Islands group (fig. 1). It is $2,337 \mathrm{~km}$ (1,452 mi) southwest of Anchorage and 1,286 km (799 mi) west of Dutch Harbor. According to the Alaska Department of Commerce, Community, and Economic Development's Community and Regional Affairs (DCCED/DCRA, 2013), military forces first came to the once uninhabited island on May 23, 1943. U.S. Air Force activities on the island were reduced after World War II, but the location provided an ideal refueling stop for Air Force planes, so the base was kept operational. In 1958, the Air Force resumed operations on Shemya Island in support of various Air Force and Army strategic intelligence collection activities. On April 6, 1993, Shemya Air Force Base was renamed Eareckson Air Station to honor Colonel William O. Eareckson who personally led all missions in 1943 against Japanese troops on the nearby Aleutian islands of Kiska and Attu. U.S. Air Force radar, surveillance, weather, and aircraft refueling stations are currently operating at Eareckson Air Station.

\section{Seismic and Tsunami History}

The rate of plate convergence in the Near Islands area of the Alaska-Aleutian megathrust is approximately $76 \mathrm{~mm}$ (3 in) per year (DeMets and others, 1990). However, unlike the central and eastern portions of the Aleutian arc that are characterized by convergence that is more-or-less normal to the trench axis, the western part of the Aleutian arc is characterized by right-lateral oblique convergence and island arc tectonics (Carver and Plafker, 2008).

The westernmost great historic earthquake along the Alaska-Aleutian subduction zone, the $\mathrm{M}_{\mathrm{W}} 8.7$ Rat Islands earthquake, occurred February 4,1965 , and was characterized by roughly $650 \mathrm{~km}$ (404 mi) of rupture (fig. 1). Although this event was quite large, damage was low because of the region's remoteness and sparse population (Johnson and Satake, 1996). The tsunami was recorded around the Pacific Ocean, but it did not cause any far-field damage. However, local waves reached $10.7 \mathrm{~m}(35 \mathrm{ft})$ on Shemya Island, causing damage to the warehouse and washing out the road (Lander, 1996). According to the Global Historical Tsunami Database of the National Centers for Environmental Information (NCEI), National Oceanic \& Atmospheric Administration (NOAA) (doi.org/10.7289/V5PN93H7), about 20 tsunamis have been recorded in Shemya, with maximum wave heights ranging from $5 \mathrm{~cm}$ ( 2 in) to $10.7 \mathrm{~m}(35.1 \mathrm{ft})$. Table 1 summarizes tsunami

Table 1. Tsunamis observed at Shemya. Data from the National Centers for Environmental Information (NCEl; formerly known as National Geophysical Data Center [NGDC]) Global Historical Tsunami Database (doi.org/10.7289/V5PN93H7).

\begin{tabular}{|c|c|c|c|}
\hline Date & Magnitude $\left(\mathbf{M}_{\mathbf{w}}\right)$ & Origin & Maximum water height $(\mathbf{m})$ \\
\hline $02 / 04 / 1965$ & 8.7 & Rat Islands, Alaska & 10.7 \\
\hline $11 / 22 / 1969$ & 7.7 & Kamchatka, Russia & 0.88 \\
\hline $02 / 17 / 1996$ & 8.2 & Indonesia & 0.35 \\
\hline $11 / 17 / 2003$ & 7.8 & Rat Islands, Alaska & 0.26 \\
\hline $11 / 15 / 2006$ & 8.3 & Kuril Islands, Russia & 0.46 \\
\hline $01 / 13 / 2007$ & 8.1 & Kuril Islands, Russia & 0.32 \\
\hline $02 / 27 / 2010$ & 8.8 & Maule, Chile & 0.39 \\
\hline $03 / 11 / / 2011$ & 9.0 & Honshu, Japan & 1.57 \\
\hline
\end{tabular}


events that produced wave heights greater than $15 \mathrm{~cm}$ (6 in).

\section{METHODOLOGY AND DATA Methodology}

The regional tsunami hazard maps presented here are the product of collaborative efforts between state and federal agencies to assist coastal communities in Alaska with tsunami hazard assessment. In recent years, similar tsunami hazard studies have been published for other communities (Nicolsky and others, 2011a; Nicolsky and others, 2013; Nicolsky and others, 2014; Suleimani and others, 2010; Suleimani and others, 2013, 2015). Because the currently available digital elevation models (DEMs) for these western Aleutian communities are of insufficient quality for high-resolution modeling, we follow the National Tsunami Hazard Mitigation Program (NTHMP, 2010) guidelines (nws.weather.gov/ nthmp/publications.html) for determining tsunami hazard zones for areas that have either low risk due to small population size and minimal infrastructure vulnerability, or do not have access to high-resolution topography. The tsunami hazard map for Shemya is developed using the methodology described in detail in Suleimani and others (2018). In short, for three scenario earthquakes, we modeled water dynamics from source to community and computed maximum tsunami wave heights using the highest resolution grids available (see table 2). Each model run covers 6 hours of post-earthquake tsunami propagation to account for all waves in the wave train, as well as secondary (reflected) wave interactions. At every location throughout the high-resolution grids, the maximum tsunami height from any of the three earthquakes is saved, and we use these maximum values to extrapolate wave runup heights on land in a new, "composite" map of maximum wave heights that can be expected from the earthquake scenarios.

\section{Computational Grids and Data Sources}

To develop a regional tsunami hazard map we use a series of nested computational grids. A nested grid allows for higher resolution in areas where it is needed without expending computer resources in areas where it is not. The bathymetric and topographic relief in each nested grid is based on DEMs developed at the NCEI. The extent of each grid used for the Shemya mapping project is shown in figure 2

Table 2. Nested grids used to compute propagation of tsunami waves generated in the Pacific Ocean to Shemya. The fine-resolution grids are used to compute the inundation. Note that the grid resolution in meters is not uniform and is used to illustrate grid fineness in the region of Shemya Island. The first dimension is the longitudinal grid resolution; the second is the latitudinal resolution.

\begin{tabular}{|c|c|c|c|c|}
\hline \multirow[b]{2}{*}{ Grid name } & \multicolumn{2}{|c|}{ Resolution } & \multirow[b]{2}{*}{ West-East boundaries } & \multirow[b]{2}{*}{ South-North boundaries } \\
\hline & Arc-seconds & $\begin{array}{c}\text { Meters } \\
\text { (near Shemya) }\end{array}$ & & \\
\hline $\begin{array}{l}\text { Level 0, Northern } \\
\text { Pacific }\end{array}$ & $120 \times 120$ & $\approx 1,850 \times 3,700$ & $120^{\circ} 00^{\prime} \mathrm{E}-100^{\circ} 00^{\prime} \mathrm{W}$ & $10^{\circ} 00^{\prime} \mathrm{N}-65^{\circ} 00^{\prime} \mathrm{N}$ \\
\hline $\begin{array}{l}\text { Level 1, Western } \\
\text { Aleutians }\end{array}$ & $40 \times 40$ & $\approx 757 \times 1233$ & $171^{\circ} 57^{\prime} 28^{\prime \prime} \mathrm{E}-172^{\circ} 10^{\prime} 40^{\prime \prime} \mathrm{W}$ & $48^{\circ} 43^{\prime} 12^{\prime \prime} \mathrm{N}-55^{\circ} 30^{\prime} 58^{\prime \prime} \mathrm{N}$ \\
\hline $\begin{array}{l}\text { Level 2, Coarse } \\
\text { resolution, Near } \\
\text { Islands }\end{array}$ & $40 / 3 \times 40 / 3$ & $\approx 249 \times 411$ & $172^{\circ} 06^{\prime} 42^{\prime \prime} E-175^{\circ} 16^{\prime} 33^{\prime \prime} \mathrm{E}$ & $51^{\circ} 44^{\prime} 51^{\prime \prime} \mathrm{N}-53^{\circ} 39^{\prime} 51^{\prime \prime} \mathrm{N}$ \\
\hline $\begin{array}{l}\text { Level 3, Fine } \\
\text { resolution, Near } \\
\text { Islands }\end{array}$ & $40 / 9 \times 40 / 9$ & $\approx 83 \times 137$ & $172^{\circ} 20^{\prime} 53^{\prime \prime} \mathrm{E}-174^{\circ} 46^{\prime} 33^{\prime \prime} \mathrm{E}$ & $52^{\circ} 07^{\prime} 12^{\prime \prime} \mathrm{N}-53^{\circ} 09^{\prime} \mathrm{N}$ \\
\hline
\end{tabular}


and listed in table 2 . The coarsest grid, level 0 , with 2-arc-minute (approximately $2 \mathrm{~km}$ [1.24 mi]) resolution, spans the central and northern Pacific Ocean. The bathymetric data for the 2-arc-minute-resolution grid is extracted from the ETOPO2 dataset (NGDC, 2006, doi.org/10.7289/V5J1012Q). We use two intermediate grids between the coarsestand highest-resolution grids (table 2). The first intermediate grid of 40 arc-second resolution (level 1) was developed to accommodate the current tsunami mapping project for Shemya as well as other tsunami mapping efforts for communities located in the Andreanof Islands (fig. 2). The data sources and methodology used to develop the 40-arc-second DEMs are described in detail by Lim and others (2011). The 40/3- and 40/9-arc-second DEMs were developed by the NCEI in the scope of NTHMP and are based on the Shemya DEM described in Carignan and others (2010).

The spatial resolution of the fine-resolution grid cells, with about $83 \times 137 \mathrm{~m}(272 \times 450 \mathrm{ft})$ dimensions, satisfies NOAA minimum recommended requirements for estimation of the tsunami hazard zone (NTHMP, 2010); however, no DEM verification efforts were conducted to reduce uncertainties in the fine-resolution (level 3) Near Islands grid. Therefore, in this report we do not perform high-resolution runup modeling, but provide an estimation of the approximate tsunami hazard zone by extrapolating the maximum composite tsunami wave height on land according to the tsunami scenarios described below. We account for uncertainties inherent to this method by applying a safety factor of 1.3 (e.g., Suleimani and others, 2018) to the estimated hazard zone.

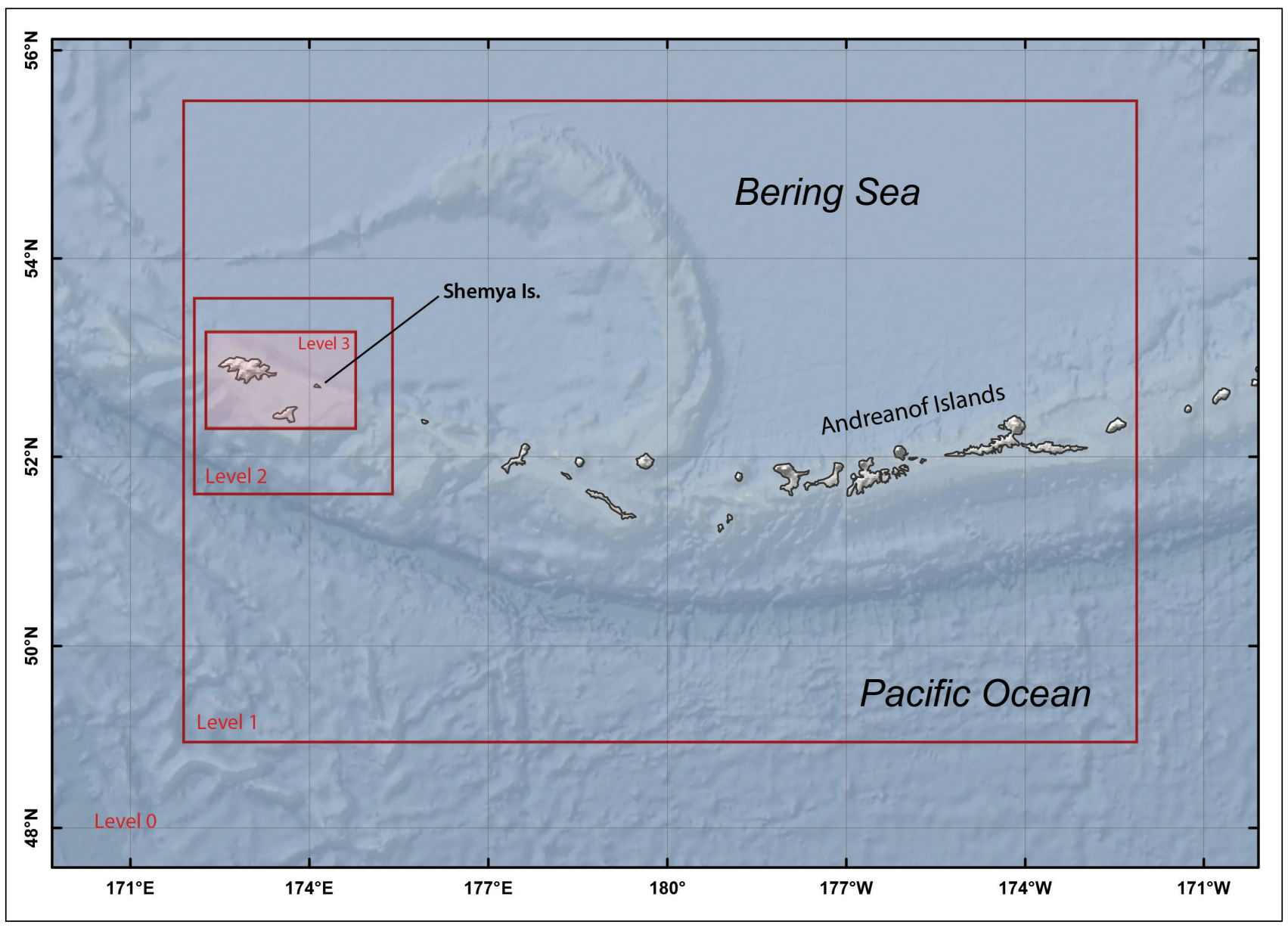

Figure 2. Nested bathymetry/topography grids for numerical modeling of tsunami propagation and runup. The coarsest grid, level 0, covers the central and northern Pacific Ocean. The location of each embedded grid is marked by a red rectangle. Refer to table 2 for grid parameters. 


\section{Tsunami Sources}

In this project we use a deterministic approach to develop potential tsunami sources, which is distinctly different from the probabilistic tsunami hazard analyses used in projects with different objectives, such as land-use planning or insurance estimates (Geist and Parsons, 2006). Alaska tsunami hazard maps are produced on the basis of significant credible tsunami scenarios for a given segment of the coastline. Although we do not explicitly develop worst-case credible tsunami scenarios for Shemya, we use the same underlying assumptions and results regarding the maximum considered scenarios for other locations along the Alaska-Aleutian subduction zone.

In this regional tsunami hazard assessment we consider three characteristic tsunamigenic earthquake scenarios (e.g., Suleimani and others, 2018). These potential megathrust ruptures have a uniform slip distribution along strike, but differ in the downdip slip distribution pattern such that the depth range at which the maximum slip occurs varies from the shallow region close to the trench to the deeper parts of the plate interface. All ruptures have the same lateral extent, which is determined by the location of communities and constrained by the maximum seismic moment. Refer to Suleimani and others (2018) for a description of the scenario development and for the proposed slip distributions.

The three characteristic tsunami scenarios for Shemya are outlined below. The vertical coseismic deformations for these scenarios are shown in figure 3. The main rupture parameters and amount of permanent subsidence in the communities are listed in table 3 .
Scenario 1. $M_{W} 9.0$ earthquake: SAFRR-type event

Scenario 2. $M_{w} 9.0$ earthquake: Maximum slip at 15-25 km (9-15 mi) depth
A hypothetical $M_{w} 9.0$ earthquake rupturing the AlaskaAleutian megathrust. During the 2011 Tohoku earthquake a large amount of slip occurred in a shallow region between the subducting and overriding plates near the Japan trench (Fujii and others, 2011; Shao and others, 2011). The USGS Science Application for Risk Reduction (SAFRR) project, in collaboration with NOAA and State of California agencies, has developed a plausible hypothetical tsunami scenario (Kirby and others, 2013) to describe the impacts of a tsunami generated by an earthquake in the Alaska Peninsula region (Ross and others, 2013). Here we assume that the slip distribution in the downdip direction is the same as that in the SAFRR source, where greater slip occurs close to the seafloor trench. This hypothetical rupture is positioned across the undersea shelf from Shemya Island. The slip is distributed almost uniformly along strike except for the edges of the rupture, where it tapers. The maximum slip of $46 \mathrm{~m}(151 \mathrm{ft})$ is at a depth of 5-15 km (3-9 mi). Vertical coseismic deformations for this scenario are shown in figure 3.

A hypothetical $\mathrm{M}_{\mathrm{W}} 9.0$ earthquake rupturing the Alaska-Aleutian megathrust. The slip is distributed almost uniformly along strike except for the edges of the rupture, where it tapers. The

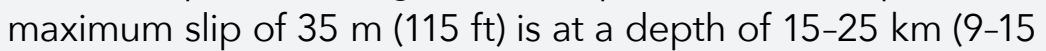
mi). Vertical coseismic deformations for this scenario are shown in figure 3. 


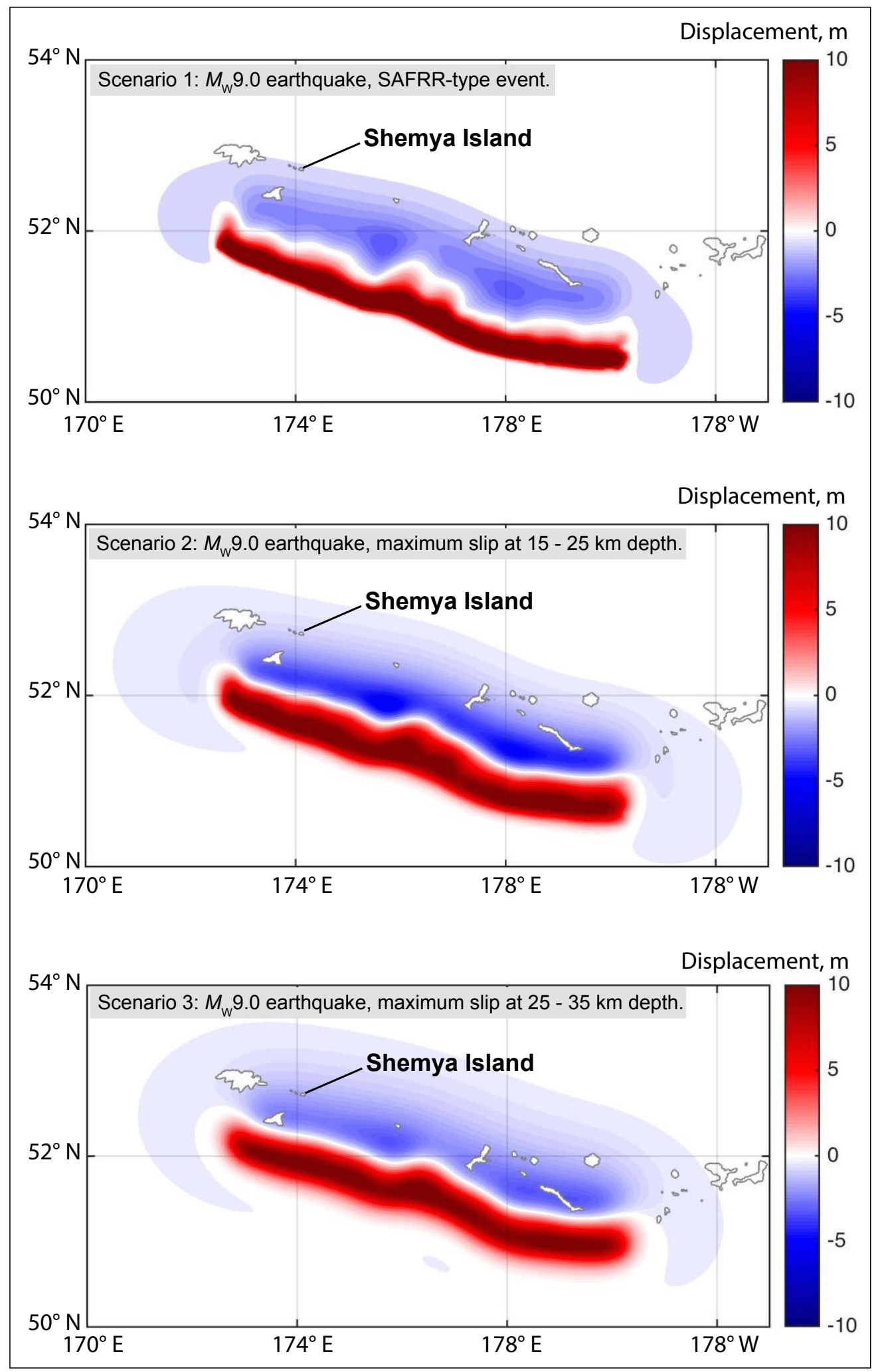

Figure 3. Vertical coseismic deformations corresponding to scenarios 1-3. Blue areas are associated with coseismic ground subsidence; areas of uplift are shown in red. 
Scenario 3. $M_{w} 9.0$ earthquake: Maximum slip at 25-35 km (15-22 mi) depth
A hypothetical $M_{W} 9.0$ earthquake rupturing the AlaskaAleutian megathrust. The slip is distributed almost uniformly along strike except for the edges of the rupture, where it tapers. The maximum slip of $35 \mathrm{~m}(115 \mathrm{ft})$ is at a depth of 25-35 km (15-22 mi). Vertical coseismic deformations for this scenario are shown in figure 3.

Table 3. Significant credible tsunami sources for Shemya. "Actual subsidence" is the subsidence that the model shows for the community, which may be (significantly) less than the maximum expected subsidence across the entire region for that same earthquake scenario.

\begin{tabular}{|c|c|c|c|c|c|c|c|}
\hline & Scenarios & $\begin{array}{c}\text { Depth range, } \\
\text { km (mi) }\end{array}$ & $\begin{array}{l}\text { Maximum slip } \\
\text { depth range, } \\
\mathrm{km}(\mathrm{mi})\end{array}$ & $\begin{array}{l}\text { Maximum slip, } \\
\mathrm{m}(\mathrm{ft})\end{array}$ & $\begin{array}{l}\text { Maximum } \\
\text { regional } \\
\text { subsidence, } \\
\mathrm{m}(\mathrm{ft})\end{array}$ & $\begin{array}{l}\text { Maximum } \\
\text { regional } \\
\text { uplift, } \\
\text { m(ft) }\end{array}$ & $\begin{array}{l}\text { Actual sub- } \\
\text { sidence in } \\
\text { Shemya, } \\
\text { m (ft) }\end{array}$ \\
\hline 1 & $\begin{array}{l}\text { Mw } 9.0 \text { earthquake: } \\
\text { SAFRR-type event, slip } \\
\text { near the trench }\end{array}$ & $\begin{array}{c}8-54 \\
(5-33)\end{array}$ & $\begin{array}{l}11-14 \\
(7-8.5)\end{array}$ & $\begin{array}{c}55-65 \\
(180-213)\end{array}$ & $\begin{array}{c}-3.1 \\
(-10.2)\end{array}$ & $\begin{array}{c}15.6 \\
(51.2)\end{array}$ & $\begin{array}{c}-0.6 \\
(-2.0)\end{array}$ \\
\hline 2 & $\begin{array}{l}\text { Mw } 9.0 \text { earthquake: } \\
\text { Maximum slip at } 15-25 \\
\text { km (9.3-15.5 mi) depth }\end{array}$ & $\begin{array}{c}5-35 \\
(3-21.7)\end{array}$ & $\begin{array}{c}15-25 \\
(9.3-15.5)\end{array}$ & $\begin{array}{c}34-35 \\
(111-115)\end{array}$ & $\begin{array}{c}-5.4 \\
(-17.7)\end{array}$ & $\begin{array}{c}12.7 \\
(41.7)\end{array}$ & $\begin{array}{c}-0.9 \\
(-3.0)\end{array}$ \\
\hline 3 & $\begin{array}{l}\text { Mw } 9.0 \text { earthquake: } \\
\text { Maximum slip at } 25-35 \\
\text { km (15.5-21.7 mi) } \\
\text { depth }\end{array}$ & $\begin{array}{l}14-45 \\
(8-26)\end{array}$ & $\begin{array}{c}25-35 \\
(15.5-21.7)\end{array}$ & $\begin{array}{c}34-35 \\
(111-115)\end{array}$ & $\begin{array}{c}-3.3 \\
(-10.8)\end{array}$ & $\begin{array}{c}11.7 \\
(38.4)\end{array}$ & $\begin{array}{l}-1.6 \\
(-5.2)\end{array}$ \\
\hline
\end{tabular}

\section{Numerical Model of Tsunami Propagation and Runup}

The numerical model currently used by the Alaska Earthquake Center (AEC) for tsunami inundation mapping is a nonlinear, flux-formulated, shallow-water model (Nicolsky and others, 2011b) that has been validated (NTHMP, 2012) through a set of analytical benchmarks and tested against laboratory and field data (Synolakis and others, 2007). The application of the model to tsunami inundation mapping of Alaska coastal communities, including its assumptions and limitations, is described in a number of previous tsunami reports; see, for example, Suleimani and others (2018). In this study we conduct all model runs using bathymetric data that correspond to the Mean Higher High Water (MHHW) tide level in Shemya Island.

For each tsunami scenario, we first calculate the maximum tsunami wave heights in the highest-resolution grid over the course of the entire model run in the following way: at each grid point, the tsunami wave height is computed at every time step during the tsunami propagation time, and the maximum value is kept. Then we compute the composite maximum wave height from all considered scenarios by again choosing the maximum value for each grid point among all scenarios, and plot the results. The plot demonstrates that runup heights differ substantially at the north and south shores.

\section{MODELING RESULTS}

Figure 4 shows maximum tsunami heights for scenarios 1-3 in the Shemya level 3 grid. In all scenarios, the tsunami energy patterns indicate concentration of the highest tsunami amplitudes along the southern shore of Shemya Island. We show the maximum composite tsunami height for all scenarios, calculated in the vicinity of Shemya Island, in figure 5. The maximum value of the tsunami height in the southern part of the island 


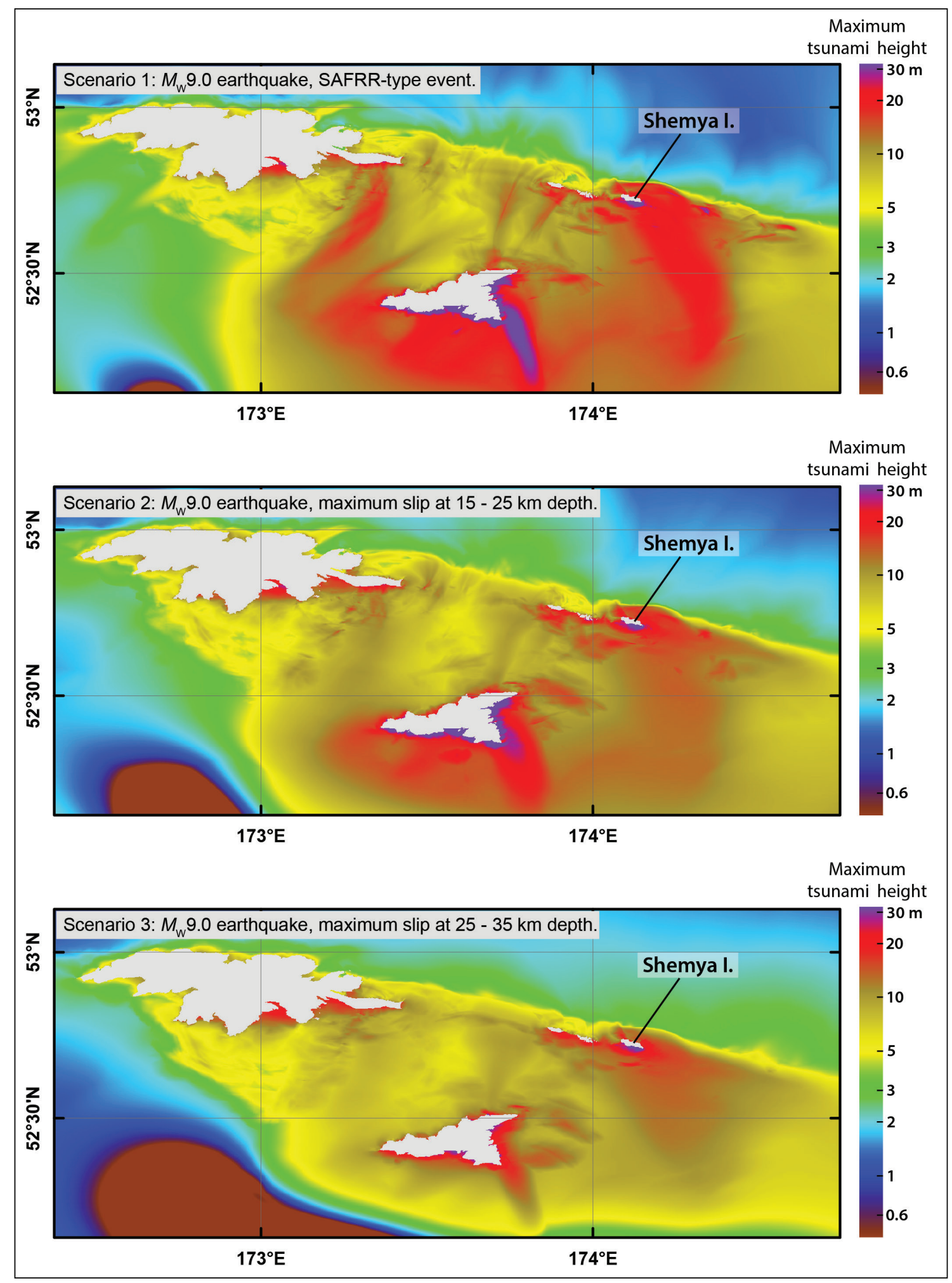

Figure 4. Maximum tsunami heights for scenarios 1-3 in the level 3 grid for Shemya Island. 


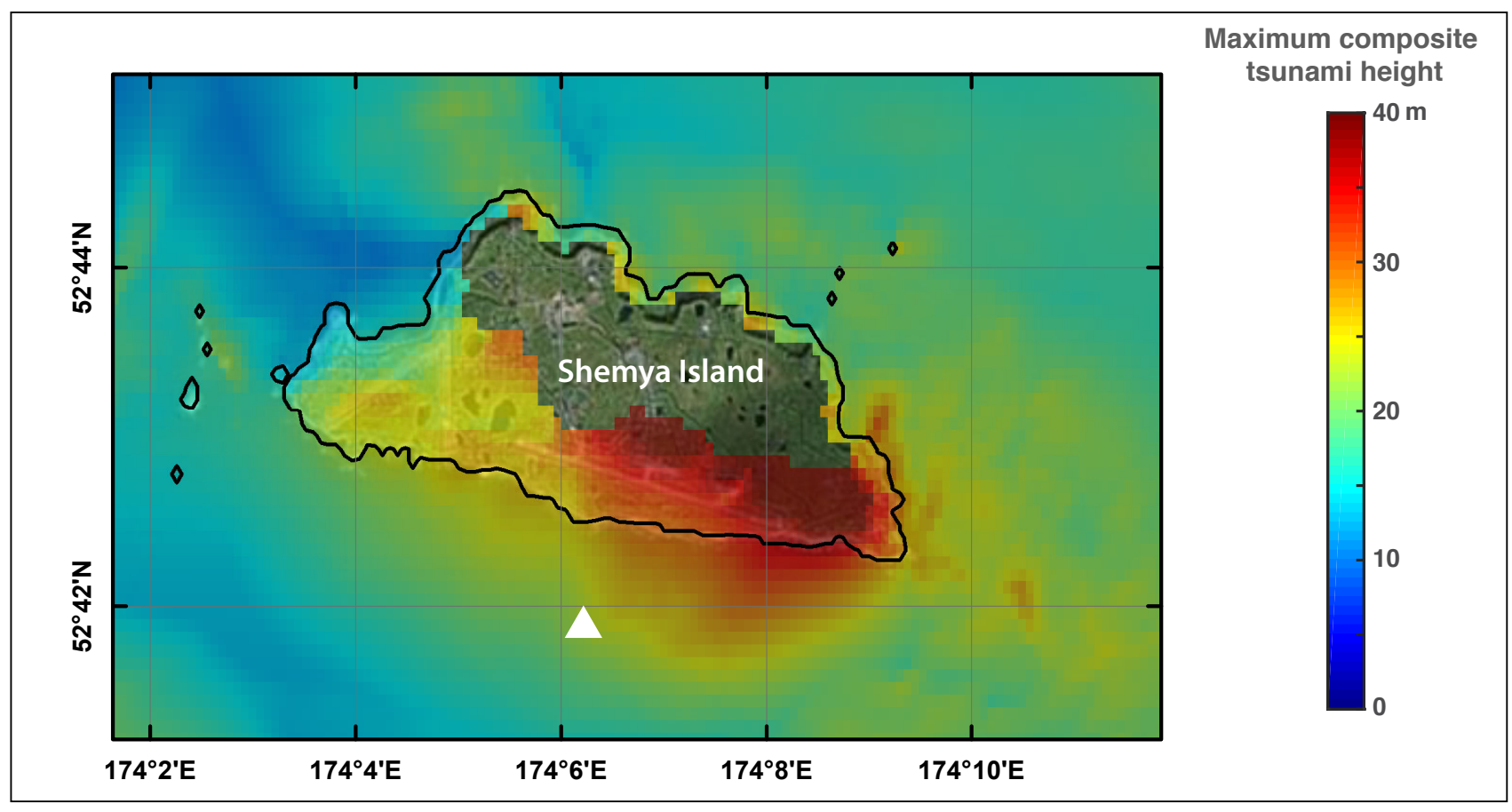

Figure 5. Maximum composite tsunami height extrapolated on Shemya Island. The white triangle indicates the location of the time series point, and the black line is the MHHW shoreline.

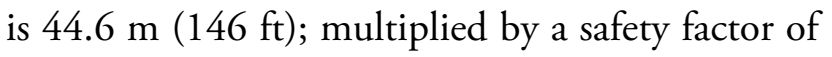
1.3 it suggests $58 \mathrm{~m}(190 \mathrm{ft})$ for the maximum estimated runup height. The maximum value of the tsunami height in the northern part of the island is $30.7 \mathrm{~m} \mathrm{(100} \mathrm{ft);} \mathrm{multiplied} \mathrm{by} \mathrm{a} \mathrm{safety} \mathrm{factor} \mathrm{of}$ 1.3 it suggests $40 \mathrm{~m}(131 \mathrm{ft})$ for the maximum estimated runup height.

Map sheet 1 illustrates the approximate tsunami hazard for Shemya, and indicates that both aircraft landing strips and most of the surrounding facilities are within the potential tsunami inundation zone. We draw two elevation contours on the community topographic map that correspond to the maximum estimated runup height for southern and northern shores. These contours approximate the boundary of the tsunami hazard zone, and should be used by emergency planners and public officials as a guideline in tsunami mitigation activities. Because no DCRA elevation data existed for Shemya, we extracted the elevation contours of 58 $\mathrm{m}(190 \mathrm{ft})$ and $40 \mathrm{~m}(131 \mathrm{ft})$ for the southern and northern parts of the island, respectively, from the 1-arc-second DEM of Shemya.
To help emergency managers understand the duration of tsunami hazards after a large megathrust earthquake, we supplement the hazard map with the time series of the modeled water level at a nearshore location (white triangle in figure 5). Time series plots are shown in figure 6 , with zero time corresponding to the time when the earthquake occurs. To compare the height of arriving tsunamis for different scenarios-which result in different values of land subsidence-we use a vertical datum with a zero mark corresponding to the post-earthquake sea level. Analysis of the time series plot shows that all scenarios result in comparable and extremely high waves at Shemya. Also, the time series plots demonstrate that dangerous waves may continue to affect the community for more than 6 hours after the earthquake.

\section{SUMMARY}

We numerically model tsunami waves generated by local hypothetical tectonic sources, analyze tsunami wave dynamics, and develop an approximate tsunami hazard map for Shemya Island. Specifically, we compute the composite maximum 


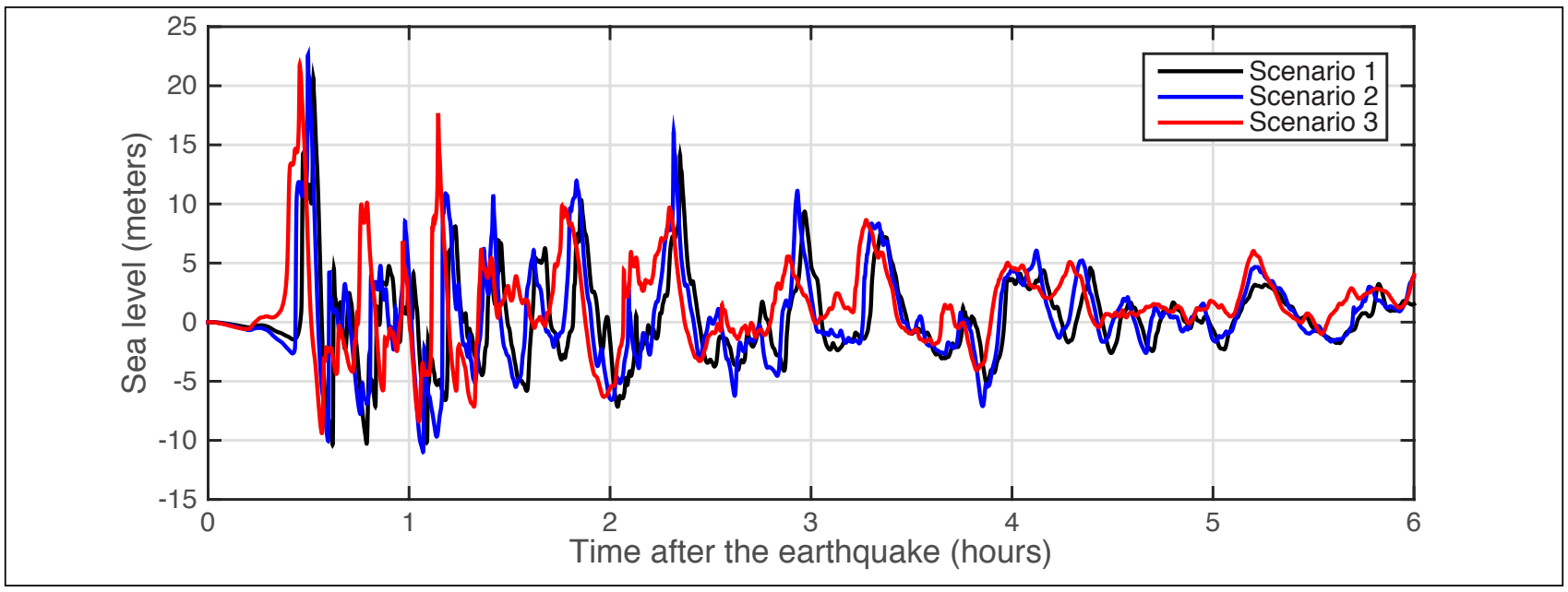

Figure 6. Time series of water level for scenarios 1-3 offshore Shemya Island calculated at the location shown as the white triangle in figure 5.

wave height from all considered scenarios and follow NTHMP guidelines to extrapolate the modeling data on land for estimation of tsunami inundation. Maximum assumed runup heights that include a 30 percent safety factor are $40 \mathrm{~m}$ $(131 \mathrm{ft})$ and $58 \mathrm{~m}(190 \mathrm{ft})$ for the north and south shores of Shemya Island, respectively.

Tsunami inundation approximations shown on the tsunami hazard map have been completed using the best information available and are believed to be accurate; however, their preparation required many assumptions. In this assessment, we estimate the potential tsunami inundation zone based on three significant tsunami scenarios. Although the modeled tsunami inundation cannot be considered exhaustive, modeling results are still thought to provide a sound approximation of the potential tsunami inundation zone in the community. Note that actual conditions during a tsunami event may vary from those considered, so the accuracy cannot be guaranteed. The limits of inundation shown should be used only as a guideline for emergency planning and response action. Actual areas inundated will depend on specifics of the earth deformation, land construction, and tide level, and may differ from areas shown on the map. The information on the hazard map is intended to assist state and local agencies in planning emergency evacuation and tsunami response actions in the event of a major tsunamigenic earthquake. These results are not intended for land-use regulation or building-code development.

\section{ACKNOWLEDGMENTS}

This project, which is part of the National Tsunami Hazard Mitigation Program (NTHMP), received support from the National Oceanic and Atmospheric Administration (NOAA) under Reimbursable Services Agreement ADN 952011 with the State of Alaska's Division of Homeland Security \& Emergency Management (a division of the Department of Military and Veterans Affairs). 


\section{REFERENCES}

Alaska Department of Commerce, Community and Economic Development, Division of Community and Regional Affairs (DCCED/DCRA), 2013, Shemya Station. dcra-cdo-dcced.opendata.arcgis.com/

Alaska Earthquake Center, University of Alaska Fairbanks Geophysical Institute. earthquake.alaska. edu

Carignan, K.S., Taylor, L.A., Eakins, B.W., Warnken, R.R., Lim, E., Grothe, P.R., and Caldwell, R.J., 2010, Digital elevation model of Shemya, AlaskaProcedures, data sources and analysis: National Oceanic and Atmospheric Administration (NOAA) Technical Memorandum NESDIS NGDC-35, 27 p. www.ngdc.noaa.gov/dem/squareCellGrid/ download/632

Carver, G.A., and Plafker, George, 2008, Paleoseismicity and neotectonics of the Aleutian subduction zone-An overview, in Freymueller, J.T., Haeussler, P.J., Wesson, R.L., and Ekström, Göran, eds., Active tectonics and seismic potential of Alaska: Washington, D.C., American Geophysical Union Geophysical Monograph, v. 179, p. 43-63. doi.org/10.1029/179GM02

DeMets, Charles, Gordon, R.C., Argus, D.F., and Stein, Seth, 1990, Current plate motions: Geophysical Journal International, v. 101, no. 2, p. 425-478. doi.org/10.1111/j.1365-246X.1990. tb06579.x

Estabrook, C.H., Jacob, K.H., and Sykes, L.R., 1994, Body wave and surface wave analysis of large and great earthquakes along the eastern Aleutian arc, 1923-1993-Implications for future events: Journal of Geophysical Research, v. 99, no. B6, p. 11,643-11,662. doi.org/10.1029/93JB03124

Fujii, Yushiro, Satake, Kenji, Sakai, Shin'ichi, Shinohara, Masanao, and Kanazawa, Toshihiko, 2011, Tsunami source of the 2011 off the Pacific coast of Tohoku earthquake: Earth Planets Space, v. 63, p. 815-820. doi.org/10.5047/eps.2011.06.010

Geist, L.G., and Parsons, T., 2006, Probabilistic analysis of tsunami hazards: Natural Hazards, v. 37, no. 3, p. 277-314. doi.org/10.1007/s11069-0054646-z
Johnson, J.M., Tanioka, Yuichiro, Ruff, L.J., Satake, Kenji, Kanamori, Hiroo, and Sykes, L.R., 1994, The 1957 great Aleutian earthquake: Pure and Applied Geophysics, v. 142, no. 1, p. 3-28. doi.org/10.1007/BF00875966

Johnson, J.M., and Satake, Kenji, 1996, The 1965 Rat Islands earthquake-A critical comparison of seismic and tsunami wave inversions: Bulletin of the Seismological Society of America, v. 86, no. 5, p. 1,229-1,237.

Kanamori, Hiroo, 1970, The Alaska earthquake of 1964-Radiation of long-period surface waves and source mechanism: Journal of Geophysical Research, v. 75, no. 26, p. 5,029-5,040. doi.org/10.1029/JB075i026p05029

Kirby, Stephen, Scholl, David, von Huene, Roland, and Wells, Ray, 2013, Alaska earthquake source for the SAFRR tsunami scenario, chapter B, in Ross, S.L., and Jones, L.M., eds., The SAFRR (Science Application for Risk Reduction) tsunami scenario: U.S. Geological Survey Open-File Report 20131170, 40 p. pubs.usgs.gov/of/2013/1170/b/

Lander, J.F., 1996, Tsunamis affecting Alaska, 1737-1996: National Oceanic and Atmospheric Administration (NOAA), National Geophysical Data Center (NGDC), Key to Geophysical Research Documentation, v. 31, 155 p.

Lim, E., Eakins, B.W., and Wigley, R., 2011, Coastal relief model of southern Alaska-Procedures, data sources and analysis: National Oceanic and Atmospheric Administration (NOAA) Technical Memorandum NESDIS NGDC-43, 22 p.

Lopez, A.M., and Okal, E.A., 2006, A seismological reassessment of the source of the 1946 Aleutian 'tsunami' earthquake: Geophysical Journal International, v. 165 , no. 3, p. 835-849. doi.org/10.1111/j.1365-246X.2006.02899.x

National Geophysical Data Center (NGDC), 2006, 2-minute Gridded Global Relief Data (ETOPO2) v2: National Geophysical Data Center (NGDC), National Oceanic and Atmospheric Administration (NOAA). doi.org/10.7289/ V5J1012Q [accessed September 8, 2015]

National Centers for Environmental Information (NCEI) , National Geophysical Data Center/World Data Service (NGDC/WDS) Global Historical 
Tsunami Database. doi.org/10.7289/V5PN93H7 [accessed September 8, 2015]

National Tsunami Hazard Mitigation Program (NTHMP), 2010, Guidelines and best practices for tsunami inundation modeling for evacuation planning: National Oceanic and Atmospheric Administration (NOAA), NTHMP Mapping \& Modeling Subcommittee.

2012, Proceedings and results of the 2011 NTHMP Model Benchmarking Workshop: Boulder, CO, U.S. Department of Commerce/ NOAA/NTHMP, NOAA Special Report, 436 p. nws.weather.gov/nthmp/

Nicolsky, D.J., Suleimani, E.N., Combellick, R.A., and Hansen, R.A., 2011a, Tsunami inundation maps of Whittier and western Passage Canal, Alaska: Alaska Division of Geological \& Geophysical Surveys Report of Investigation 2011-7, 65 p. doi. org/10.14509/23244

Nicolsky, D.J., Suleimani, E.N., Haeussler, P.J., Ryan, H.F., Koehler, R.D., Combellick, R.A., and Hansen, R.A., 2013, Tsunami inundation maps of Port Valdez, Alaska: Alaska Division of Geological \& Geophysical Surveys Report of Investigation 2013-1, 77 p., 1 sheet, scale 1:12,500. doi. org/10.14509/25055

Nicolsky, D.J., Suleimani, E.N., and Hansen, R.A., 2011b, Validation and verification of a numerical model for tsunami propagation and runup: Pure and Applied Geophysics, v. 168, p. 1,199-1,222. doi.org/10.1007/s00024-010-0231-9

Nicolsky, D.J., Suleimani, E.N., and Koehler, R.D., 2014, Tsunami inundation maps of Cordova and Tatitlek, Alaska: Alaska Division of Geological \& Geophysical Surveys Report of Investigation 20141, 49 p. doi.org/10.14509/27241

Ross, S.L., Jones, L.M., Miller, Kevin, Porter, K.A., Wein, A., Wilson, R.I., Bahng, Bohyun, Barberopoulou, Aggeliki, Borrero, J.C., Brosnan, D.M., Bwarie, J.T., Geist, E.L., Johnson, L.A., Kirby, S.H., Knight, W.R., Long, Kate, Lynett, Patrick, Mortensen, C.E., Nicolsky, D.J., Perry, S.C., Plumlee, G.S., Real, C.R., Ryan, Kenneth, Suleimani, Elena, Thio, H.K., Titov, V.V., Whitmore, P.M., and Wood, N.J., 2013, SAFRR (Science Application for Risk Reduction) tsunami
scenario-Chapter A, Executive summary and introduction, in Ross, S.L., and Jones, L.M., eds., The SAFRR tsunami scenario: U.S. Geological Survey Open-File Report 2013-1170, p. 1-17. pubs.usgs.gov/of/2013/1170/

Shao, Guangfu, Li, Xiangyu, Ji, Chen, and Maeda, Takahiro, 2011, Focal mechanism and slip history of $2011 \mathrm{M}_{\mathrm{W}} 9.1$ off the Pacific coast of Tohoku earthquake, constrained with teleseismic body and surface waves: Earth Planets Space, v. 63, no. 7, p. 559-564. doi.org/10.5047/eps.2011.06.028

Suleimani, E.N., Nicolsky, D.J., and Koehler, R.D., 2013, Tsunami inundation maps of Sitka, Alaska: Alaska Division of Geological \& Geophysical Surveys Report of Investigation 2013-3, 76 p., 1 sheet, scale 1:250,000. doi.org/10.14509/26671

Suleimani, E.N., Nicolsky, D.J., and Koehler, R.D., 2015, Tsunami inundation maps of Elfin Cove, Gustavus, and Hoonah, Alaska: Alaska Division of Geological \& Geophysical Surveys Report of Investigation 2015-1, 79 p. doi.org/10.14509/29404

Suleimani, E.N., Nicolsky, D.J., Koehler, R.D., and Salisbury, J.B., 2018, Regional tsunami hazard assessment for Andreanof Islands, Alaska: Alaska Division of Geological \& Geophysical Surveys Report of Investigation 2017-2, 19 p., 2 sheets. doi. org/10.14509/29704

Suleimani, E.N., Nicolsky, D.J., West, D.A., Combellick, R.A., and Hansen, R.A., 2010, Tsunami inundation maps of Seward and Northern Resurrection Bay, Alaska: Alaska Division of Geological \& Geophysical Surveys Report of Investigation 2010-1, 47 p., 3 sheets, scale 1:12,500. doi.org/10.14509/21001

Synolakis, C.E., Bernard, E.N., Titov, V.V., Kânoğlu, U., and González, FI., 2007, Standards, criteria, and procedures for NOAA evaluation of tsunami numerical models: Seattle, WA, NOAA/Pacific Marine Environmental Laboratory (PMEL), Technical Memorandum OAR PMEL-135, 55 p.

Wu, FT., and Kanamori, Hiroo, 1973, Source mechanism of February 4, 1965, Rat Island earthquake: Journal of Geophysical Research, v. 78, no. 26, p. 6,082-6,092. doi.org/10.1029/ JB078i026p06082 